\title{
PENGEMBANGAN CD INTERAKTIF PADA MATA PELAJARAN MATEMATIKA MATERI KEKONGRUENAN DAN KESEBANGUNAN BANGUN DATAR KELAS IX SMP/MTs.
}

\author{
Imam Baehaqi ${ }^{1}$, Asri Widiatsih ${ }^{2}$, I Wayan Wisa Atmaja ${ }^{3}$ \\ MTs. Nahdlatuth Thalabah ${ }^{1}$, IKIP PGRI Jember ${ }^{2}$, IKIP PGRI Jember ${ }^{3}$ \\ Imambaehagi81@gmail.com, asriwidiatsih@ikipjember.ac.id, iwayanwisaatmaja@ikipjember.ac.id
}

\begin{abstract}
Education must be planned systematically, so that an interesting and enjoyable learning atmosphere can run optimally. With the formation of an interesting and fun learning atmosphere, students will actively develop their potential according to their talents and interests. One of the planning in the learning process is the presence of media, the obscurity and complexity of teaching materials can be simplified with the media as an intermediary. Therefore, this study is aimed at developing elearning based media at NahdlatuthThalabah Junior High School. This research type is Research and Development (R \& D) with Hannafin and Peck development model which consists of three stages, namely need analysis, design, development and implementation. The trial subject was student of class IX A of NahdlatuthThalabah Junior High School. The study results are in the form of interactive CD In Mathematics Materials Congression And Construction Figure For Class IX Junior High School. Product quality assessment developed consists of three aspects, namely (1) Validity, is assessed from the results of assessment by experts, including: assessment of media expert is , material experts is , RPP assessment is, all of them in valid classifications. (2) Practicality is assessed from the results of observations of learning is $80 \%$ with good classification. (3) Effectiveness is assessed from the observations of the student activities who get a score of $80 \%$ with a very good classification, the results of responses of students get a score of 4 with good classification, the results of the educator response get a score of 4 with a good classification and test results with $80 \%$ completeness including good classification. Based on the results above, so the media which is developed declared valid, practical and effective.
\end{abstract}

Keywords: Interactice CD, Matemathic, MTs

\begin{abstract}
Abstrak : Pendidikan harus direncanakan secara sistematis agar suasana belajar dapat menarik, menyenangkan dan berjalan secara maksimal. Terbentuknya suasana belajar yang menarik serta menyenangkan, membuat Peserta didik aktif mengembangkan potensi sesuai dengan bakat dan minatnya. Salah satu perencanaan dalam proses pembelajaran adalah dengankehadiran media, ketidakjelasan dan kerumitan bahan ajar dapat disederhanakandengan media sebagai perantara. Oleh karena itu, penelitian ini ditujukan untuk mengembangkan media pembelajaran di MTs.NahdlatuthThalabah. Jenis penelitian ini adalah Research and Development (R\&D) dengan model pengembangan Hannafin dan Peck yang terdiri dari tiga tahap yaitu need analysis, design, development and implementation. Subjek uji coba yaitu peserta didik kelas IX A MTs.NahdlatuthThalabah. Hasil dari penelitian ini berupa CD Interaktif pada mata pelajaran matematika materi kekongruenan dan kesebangunan. Penilaian kualitas produk yang dikembangkan terdiri dari tiga aspek yaitu (1) Kevalidan diperoleh dari hasil penilaian para ahli, diantaranya : penilaian media memperoleh skor 4,6, penilaian materi memperoleh skor 4,1, penilaian RPP sebesar 4,1, kesemuanya dalam klasifikasi valid. (2) Kepraktisan dinilai dari hasil pengamatan keterlaksanaan pembelajaran yang memperolehskor $80 \%$ dengan klasifikasi baik. (3) Keefektifan dinilai dari hasil pengamatan aktivitas peserta didik yang memperoleh skor 80\% dengan klasifikasi sangat baik, hasil respon peserta didik memperoleh skor 4 dengan klasifikasi baik, hasil respon pendidik memperoleh skor 4 dengan klasifikasi baik dan tes hasil belajar memperoleh ketuntasan $80 \%$ dengan klasifikasi baik. Berdasarkan hasil diatas maka media yang dikembangkan dinyatakan valid, praktis dan efektif.
\end{abstract}




\section{PENDAHULUAN}

Undang-undang No 20 Tahun 2003 tentang Sistem Pendidikan Nasional menyatakan bahwa : "Pendidikan adalah usaha sadar dan terencana untuk mewujudkan suasana belajar dan proses pembelajaran agar peserta didik secara aktif mengembangkan potensi dirinya untuk memiliki kekuatan spiritual keagamaan, pengendalian diri, kepribadian, kecerdasan, akhlak mulia, serta ketrampilan yang diperlukan dirinya, masyarakat, bangsa dan negara.” Berdasarkan pengertian tersebut dapat dipahami bahwa pendidikan itu harus disadari arti pentingnya, dan direncanakan secara sistematis, agar suasana belajar yang menarik dan menyenangkan dapat berjalan secara optimal. Terbentuknya suasana belajar yang menarik dan menyenangkan, akan membuat peserta didik aktif untuk mengembangkan potensi sesuai dengan bakat dan minatnya. Berkembangnya potensi peserta didik akan memiliki kekuatan spiritual keagamaan, pengendalian diri, kepribadian, kecerdasan, akhlak mulia, serta ketrampilan yang diperlukan dirinya, masyarakat bangsa dan negara.

Pendidik sebagai barisan terdepan suksesnya pendidikan diharuskan memiliki keahlian dan kreativitas yang mumpuni agar dapat mengemas proses pembelajaran di kelas sesuai yang diamanatkan. Kehadiran media pembelajaran mempunyai makna yang cukup penting, ketidakjelasan materi yang disampaikan dapat dibantu dengan menghadirkan media sebagai perantara. Kerumitan bahan yang akan disampaikan kepada anak didik dapat disederhanakan dengan bantuan media. Media dapat mewakili apa yang kurang mampu pendidik ucapkan melalui kata-kata atau kalimat tertentu, bahkan keabstrakan bahan dapat dikonkretkan dengan kehadiran media.

Pentingnya media dalam pembelajaran matematika membuat pendidik di MTs. Nahdlatuth Thalabah yaitu Bapak Nanang Arifin, S.Pd terus berusaha mengembangkan media pembelajaran yang relevan dan mendukung bagi kebutuhan peserta didik dan tetap memperhatikan aspek pedagogis dan kurikulum yang harus dicapainya. Pengembangan media pembelajaran berbasis komputer memungkinkan terciptanya multimedia pembelajaran Matematika yang lebih interaktif dan efektif dalam pembelajaran. Muatan materi Matematika yang disertai gambar dan audio membuat multimedia tersebut mampu menyajikan materi dengan lebih jelas. Tampilan materi dan gambar dapat diatur dengan menggunakan animasi yang bisa disesuaikan untuk mendukung penyajian materi sesuai dengan konsep yang benar, sehingga dapat membantu peserta didik dalam 
pengamatan dan pemberian perhatian terhadap pembelajaran untuk lebih memahami konsep materi yang dipelajari.

Observasi awal untuk mengetahui permasalahan proses pembelajaran pada mata pelajaran matematika dilakukan di dua tempat yakni SMP Nahdlatuth Tholabah Kesilir Wuluhan Jember dan MTs. Nahdlatuth Thalabah Kesilir Wuluhan Jember, dalam pengamatan yang dilakukan peneliti terhadap sekolah menengah pertama dan madrasah tsanawiyah, selama proses pembelajaran matematika berlangsung ditemukan bahwa pendidik di dua sekolah tersebut masih menggunakan metode pembelajaran konvensional (ceramah), meskipun kadang-kadang membawa alat peraga berupa kerangka model. Tersedianya laboratorium komputer maupun LCD Proyektor kurang dimanfaatkan oleh pendidik. Hal ini tentu sangat menyulitkan peserta didik untuk memahami matematika yang bersifat abstrak. Selama proses pembelajaran untuk mendiskripsikan makna dari kekongruenan dan kesebangunan bangun datar, pendidik langsung menyebutkan sifat-sifat dan menggambarkan contoh bangun datar tersebut pada papan tulis. Tugas peserta didik selanjutnya adalah mencatat dan menghafalkan materi tersebut. Hal itu kurang efisien karena tidak menutup kemungkinan peserta didik akan lupa dengan materi tersebut. Tapi akan berbeda, jika peserta didik dilibatkan dalam mencari darimana sifat-sifat itu ditemukan, bagaimana kekongruenan itu dibuat dan sebagainya. Dari sanalah pembentukan konsep berperan memberikan pengalaman yang tidak akan mudah dilupakan oleh peserta didik. Pendidik harus ingat bahwa peserta didik bukanlah benda mati yang tidak memiliki potensi apapun kecuali hanya menerima apa yang kita sampaikan,tetapi peserta didik adalah makhluk hidup yang masing-masing juga memiliki potensi luar biasa untuk digali dan dikembangkan. Maka disinilah peran pendidik diperlukan untuk membimbing peserta didik dalam menemukan pengetahuan mereka sendiri dengan menghubungkan materi-materi tersebut dengan kehidupan nyata sehari-hari.

Usaha yang dapat dilakukan dalam rangka efektifitas proses belajar peserta didik dan mengkonkretkan hal-hal yang bersifat abstrak yaitu dengan menggunakan CD Interaktif pembelajaran matematika. CD Interaktif akan sangat membantu anak-anak yang daya tilik ruang dan kemampuan belajar melalui telinganya kurang. Konsep abstrak matematika yang disajikan dalam bentuk konkret akan lebih dapat dipahami dan dimengerti serta dapat ditanamkan pada tingkat yang lebih rendah. Penting bagi seorang pendidik untuk mengembangkan CD Interaktif agar peserta didik merasa nyaman belajar di dalam kelas, sehingga mereka mampu menyerap segala materi pembelajaran dengan baik dan tujuan pembelajaran dapat tercapai.

Berdasarkan teori Piaget (Mukhlisah AM. 2015) menyatakan : "pada awalnya anak belajar melalui hal-hal yang konkret. Untuk memahami konsep matematika yang bersifat abstrak, anak memerlukan benda-benda konkret atau real sebagai visualisasinya." Dalam tahap periode terakhir 
perkembangan kognitif. Tahap ini mulai dialami anak dalam usia sebelas tahun dan terus berlanjut sampai dewasa. Karakteristik tahap ini adalah diperolehnya kemampuan untuk berpikir secara abstrak, menalar secara logis, dan menarik kesimpulan dari informasi yang tersedia. Dalam tahapan ini, seseorang dapat memahami hal-hal seperti cinta, bukti logis, dan nilai.

Kegiatan belajar mengajar yang diikuti dengan pemakaian media sangat besar artinya bagi keberhasilan belajar peserta didik, karena akan membantu peserta didik untuk lebih memahami dan menguasai materi yang diajarkan. Penggunaan media dalam pembelajaran, peserta didik dapat melihat, meraba, mengungkapkan dengan memikirkan secara langsung obyek yang sedang mereka pelajari, sehingga konsep abstrak yang baru dipahami itu mengendap, melekat dan tahan lama bila ia belajar melalui berbuat dan pengertian, bukan hanya melalui mengingat-ingat fakta. Dapat disimpulkan penggunaan media dalam pembelajaran matematika sangat diperlukan untuk mempermudah pemahaman konsep-konsep matematika yang bersifat abstrak melalui pemberian pengalaman belajar kepada peserta didik.

Banyak alternatif untuk menciptakan pembelajaran yang menarik dan memudahkan belajar peserta didik sehingga mampu membangkitkan semangat untuk belajar, untuk menciptakan tersebut antara lain dengan melengkapi sarana dan prasarana pembelajaran, serta diperkaya oleh sumbersumber belajar yang memadai juga didukung dengan inovasi media pembelajaran. Inovasi media pembelajaran tersebut digunakan untuk meningkatkan kualitas pembelajaran. Produk teknologi yang dapat digunakan sebagai inovasi dalam pembelajaran adalah komputer. Hal tersebut sesuai dengan pernyataan Surjono (1995: 2) bahwa "komputer sebagai salah satu produk teknologi dinilai tepat digunakan sebagai alat bantu pengajaran."

Salah satu media pembelajaran dengan menggunakan teknologi komputer yaitu Media CD Interaktif. CD Interaktif dipilih karena didalamnya dapat memadukan media-media dalam proses pembelajaran, seperti kombinasi antara teks, gambar, suara, video dan animasi dapat menjadi satu kesatuan sehingga memungkinkan penggunanya dapat melakukan navigasi, berinteraksi, berkreasi dan berkomunikasi. Proses penggunaan CD Interaktif sangat memungkinkan dilaksanakan. Sebagian besar pendidik mempunyai laptop dan tersedianya lab komputer bagi peserta didik serta LCD proyektor yang dapat digunakan sewaktu-waktu sebagai penunjang pembelajaran.

Sudjana dan Rivai (2013:2) mengatakan "media pengajaran dapat memudahkan proses belajar peserta didik dalam pengajaran yang pada gilirannya diharapkan dapat menghasilkan hasil belajar yang ingin dicapai. Alasannya berkenaan dengan manfaat media pengajaran dalam proses belajar peserta didik antara lain: (1) pengajaran akan lebih menarik perhatian peserta didik sehingga dapat menumbuhkan motivasi belajar, (2) bahan pengajaran akan lebih jelas maknanya sehingga akan lebih dipahami oleh para peserta didik dan memungkinkan peserta didik mengusai tujuan pengajaran lebih 
baik, (3) metode pengajaran akan lebih bervariasi, (4) peserta didik lebih banyak melakukan kegiatan belajar sebab tidak hanya mendengarkan uraian pendidik tetapi juga aktivitas lain seperti mengamati, melakukan, dan mendemontrasikan.”

Keunggulan pembelajaran dengan media pembelajaran berupa CD Interkatif diungkapkan lebih lanjut oleh Susilana dan Riyana (2009: 126-127) "kelas yang belajar dengan menggunakan komputer atau computer assisted instruction (CAI) dibandingkan dengan kelas yang menggunakan tatap muka. Hasilnya menunjukkan bahwa terjadi penghematan waktu yang signifikan. Peserta didik yang menggunakan program komputer dapat menyelesaikan pelajaran rata-rata 13,75 jam sedangkan kelompok yang menggunakan tatap muka memerlukan waktu 24 jam."

Penjelasan tersebut mengandung makna bahwa pembelajaran dengan memanfaatkan CD interaktif ternyata menguntungkan karena dapat menghemat waktu.

Depdiknas (2007: 2) juga menyimpulkan bahwa media pembelajaran memiliki keunggulan dalam hal:"1) Memperbesar benda yang sangat kecil dan tidak tampak oleh mata, seperti kuman, bakteri, elektron; 2) Memperkecil benda yang sangat besar, yang tidak mungkin dihadirkan ke sekolah, seperti gajah, rumah, gunung; 3) Menyajikan benda atau peristiwa yang kompleks, rumit dan berlangsung cepat atau lambat, seperti sistem tubuh manusia, bekerjanya suatu mesin, beredarnya planet, berkembangnya bunga; 4) Menyajikan benda atau peristiwa yang jauh, seperti bulan, bintang, salju; 5) Menyajikan benda atau peristiwa yang berbahaya, seperti letusan gunung berapi, harimau, racun; dan , 6) Meningkatkan daya tarik dan perhatian peserta didik."

Menurut uraian di atas dapat dikemukakan bahwa penggunaan media dalam pembelajaran memiliki keunggulan yang mendekati sistem pembelajaran secara langsung (contextual learning). Kelebihannya, sesuatu yang tidak dapat dicapai dengan contextual learning, dapat diwujudkan dengan bantuan media meskipun di sisi lain masih terdapat beberapa keterbatasan. Penelitian terdahulu dalam jurnal yang berjudul "Pengembangan Media CD Interaktif Matematika Untuk Meningkatkan Kemampuan Pemecahan Masalah Siswa SMP” (Hevy Risqi Maharani \& M. Abdul Basir, 2016) "penggunaan media pembelajaran CD interaktif dalam pemecahan masalah geometri pada bangun ruang prisma dan limas sebagai penunjang pembelajaran untuk meningkatkan kemampuan pemecahan masalah siswa SMP. Hasil penilaian validator menunjukkan CD interaktif pada kategori sangat baik dengan skor rata -rata 4,23 dari rentang maksimal 5. Uji kepraktisan CD interaktif ditunjukkan dengan adanya respon positif dari guru dan siswa. Hasil uji efektivitas diperoleh bahwa $\mathrm{CD}$ interaktif efektif dalam meningkatkan kemampuan pemecahan masalah. Hal ini ditunjukkan dengan rata-rata kemampuan pemecahan masalah siswa yang menggunakan $\mathrm{CD}$ interaktif mencapai ketuntasan individu dan klasikal. Selain itu, rata-rata kemampuan pemecahan 
masalah siswa yang menggunakan CD interaktif lebih baik dibandingkan dengan yang tidak menggunakan CD interaktif."

Penggunaan CD Interaktif diharapkan dapat menumbuhkan motivasi belajar peserta didik terutama pada mata pelajaran matematika dan dapat membantu peserta didik menguasai materi tentang kekongruenan dan kesebangunan bangun datar dengan lebih mudah karena peserta didik dilibatkan secara langsung dalam proses pembelajaran.

Latar belakang tersebut memberikan inspirasi kepada peneliti untuk mengadakan penelitian dengan judul "Pengembangan CD Interaktif Pada Mata Pelajaran Matematika Materi Kekongruenan dan Kesebangunan Bangun Datar Untuk Kelas IX SMP/MTs.

Tujuan penelitian dan pengembangan ini sesuai dengan masalah diatas adalah sebagai berikut :1) Mengetahui proses pengembangan $\mathrm{CD}$ interaktif pada mata pelajaran matematika materi kekongruenan dan kesebangunan bangun datar untuk kelas IX SMP/MTs.2) Mengetahui kevalidan produk CD interaktif pada mata pelajaran matematika materi kekongruenan dan kesebangunan bangun datar untuk kelas IX SMP/MTs.3) Mengetahui kepraktisan dan keefektifan penggunaan CD interaktif pada mata pelajaran matematika materi kekongruenan dan kesebangunan bangun datar untuk kelas IX SMP/MTs.

\section{METODE}

Jenis penelitian ini adalah penelitian pengembangan dengan model pengembangan Hanafin and Peck yang terdiri dari 1) analisis kebutuhan, 2) Desain, 3) Pengembangan dan Implementasi. pemilihan model pengembangan ini sesuai dengan tujuan desain pembelajaran yang orientasinya berupa produk media pembelajaran.

Subyek uji coba pada pengembangan CD Interaktif adalah peserta didik kelas IX di MTs. Nahdlatuth Thalabah berjumlah 25 orang. Penelitian ini dimulai pada januari tahun 2018 dan pelaksanaan ujicoba dilaksanakan pada bulan september 2018.

Dalam penelitian ini digunakan beberapa instrumen yang mendukung peneliti untuk mendapatkan data tentang kevalidan, keefektifan dan kepraktisan CD Interaktif antara lain : lembar angket, lembar observasi dan soal tes.

Data hasil penelitian yang diperoleh harus dianalisis menggunakan beberapa teknik analisis data sebagai berikut:

Analisis data kevalidan diperoleh dari penilaian RPP, penilaian oleh ahli media dan ahli materi dalam hal ini validator untuk ahli media yaitu Dedy Ariyanto, S.Pd., M.Pd dan validator untuk ahli materi yaitu Dr. Hobri, M.Pd. 
Tabel 1. Klasifikasi Penilain Kevalidan

\begin{tabular}{ll}
\hline \multicolumn{1}{c}{ Interval Skor } & \multicolumn{1}{c}{ Klasifikasi } \\
\hline $1 \leq \mathrm{Va}<2$ & Tidak Valid \\
$2 \leq \mathrm{Va}<3$ & Kurang Valid \\
$3 \leq \mathrm{Va}<4$ & Cukup Valid \\
$4 \leq \mathrm{Va}<5$ & Valid \\
$\mathrm{Va}=5$ & Sagat Valid \\
\hline
\end{tabular}

Sumber : (Hobri, 2010:53)

Keterangan: Va adalah nilai penentuan tingkat kevalidan

Analisis data kepraktisan CD Interaktif diperoleh dari observasi keterlaksanaan pembelajaran di kelas.

Tabel 2. Klasifikasi Penilaian Keterlaksanaan Pembelajaran

\begin{tabular}{|c|c|}
\hline Interval Skor & Klasifikasi \\
\hline$p \geq 90 \%$ & Sangat Baik \\
\hline $80 \% \leq p<90 \%$ & Baik \\
\hline $70 \% \leq p<80 \%$ & Cukup \\
\hline$P<70 \%$ & Kurang \\
\hline
\end{tabular}

Sumber : Nasiroh (2014)

Analisis data keefektifan didapatkan dari pengamatan aktivitas peserta didik, angket respon pendidik dan peserta didik dan hasil belajar peserta didik setelah menggunakan CD Interaktif.

Tabel 3. Klasifikasi Penilaian AktifitasPeserta Didik

\begin{tabular}{c:c}
\hline Interval Skor & Klasifikasi \\
\hline $\mathbf{p}<\mathbf{2 0} \%$ & Sangat Buruk \\
$\mathbf{2 0} \% \leq \mathbf{p}<\mathbf{4 0} \%$ & Buruk \\
$\mathbf{4 0} \% \leq \mathbf{p}<\mathbf{6 0 \%}$ & Cukup \\
$\mathbf{6 0} \% \leq \mathbf{p}<\mathbf{8 0} \%$ & Baik \\
$\mathbf{8 0} \% \leq \mathbf{p}$ & Sangat Baik \\
\hline
\end{tabular}

Sumber : Riduwan (2015:15)

Data hasil penilaian pengamatan aktivitas peserta didik dianalisis untuk mencari skor rata-rata dengan rumus :

$$
\text { Ps }=\frac{A}{N} \times 100 \%
$$

Keterangan :

$\mathrm{PS}_{\mathrm{S}}=$ Presentasekeaktivanpesertadidik

A=Jumlahskoryangdiperolehpesertadidik

$\mathrm{N}=$ Jumlahskorseluruhnya". 
Tabel4.KlasifikasiPenilaianResponPendidikdanPesertaDidik

\begin{tabular}{cc}
\hline Interval Skor & Klasifikasi \\
\hline$X>4,2$ & Sangat Baik \\
$3,4<X \leq 4,2$ & Baik \\
$2,6<X \leq 3,4$ & Cukup \\
$1,8<X \leq 2,6$ & Kurang \\
$X \leq 1,8$ & Sangat Kurang \\
\hline
\end{tabular}

Sumber: Nasiroh(2014)

Rumusyang digunakanuntukmenghitungskorrata-rata untuktiapaspekadalah :

$$
\bar{x}=\frac{\sum_{i=1}^{n} x_{i}}{n}
$$

Keterangan :

$\overline{\boldsymbol{x}}$

: skorrata-ratamasing-masingaspekyangdiamati

$\sum_{i=1}^{n} x_{i} \quad$ : jumlahskormasing-masingaspekyangdiamati

$\mathrm{N} \quad$ : banyaknyabutirpenilaianmasing-masingaspekyang diamati

Tabel5.KlasifikasiPenilaianKeefektifan

HasilBelajarPesertaDidik

\begin{tabular}{cc}
\hline Ketuntasan & Klasifikasi \\
\hline $90 \%<\mathrm{X} \leq 100 \%$ & Sangat Baik \\
$80 \%<\mathrm{X} \leq 90 \%$ & Baik \\
$65 \%<\mathrm{X} \leq 80 \%$ & Cukup \\
$55 \%<\mathrm{X} \leq 65 \%$ & Kurang \\
$\mathrm{X} \leq 55 \%$ & Sangat \\
& Kurang \\
\hline
\end{tabular}

Sumber:M.NgalimPurwanto(Nashiroh 2014:82)

\section{HASIL DAN PEMBAHASAN}

Penelitian yang dilakukan menghasilkan sebuah CD Interaktif Pembelajaran Matematika Materi Kekongruenan Dan Kesebangunan Bangun Datar.

Langkah pertama dalam penelitian ini adalah Analisis yang bertujuan untuk mengetahui kebutuhan terhadap media pembelajaran sekaligus mengetahui proses pembelajaran 
matematika di kelas IX A di MTs. Nahdlatuth Thalabah. Analisis kebutuhan terdiri dari dari (1) analisis kebutuhan peserta didik meliputi kemampuan peserta didik pada mata pelajaran matematika, gaya belajar siswa dan pilihan media yang akan dikembangkan. Hasil analisis tersebut didapat bahwa gaya belajar peserta didik yang beraneka ragam dan peserta didik memilih unutk pengembangan media menggunakan CD Interaktif. analisis kebutuhan pendidik didapatkan dari hasil wawancara kepada pendidik mata pelajaran matematika yaitu Nanang Arifin, S.Pd. Hasil wawancara dengan pendidik mata pelajaran matematika menyatakan permasalahan pembelajaran dari sudut pandang pendidik yaitu kesulitan pendidik dalam menyampaikan materi karena peserta didik kurang fokus saat pembelajaran berlangsung. (2) analisis peserta didik, dari hasil analisis tersebut didapat rata-rata usia 14-15 tahun dan mayoritas berasal dari SD/MI swasta dengan gaya belajar peserta didik yang bermacammacam. (3) analisis tujuan untuk mengetahui kompetensi yang harus dicapai peserta didik. (4) analisis setting pembelajaran digunakan untuk memilih metode dan media pembelajaran yang akan digunakan, metode diskusi dan tanya jawab serta menggunakan CD Interakif yang dipilih.

Langkah kedua dalam penelitian ini adalah fase desain yang berisi pembuatan story board CD Interaktif, menyusun instrumen penelitian yang akan digunakan, menyusun RPP dan soal tes.

Langkah ketiga yakni pengembangan dan implementasi. Peneliti melakukan pembuatan CD Interaktif yang selanjutnya divalidasi oleh validator dan adanya revisi yang harus dilakukan. RPP juga divalidasi untuk mengetahui kelayakannya. Tampilan CD interaktif pembelajaran matemtika materi kekongruenan dan kesebangunan bangun datar terdiri dari (1) halaman Pembuka, (2) halaman utama, (3) halaman materi, (4) halaman identitas evaluasi, (5) halaman soal.

\section{Hasil Tampilan Halaman Pembuka}

Tampilan ini merupakan halaman pembuka. Tampilan ini terdapat slide gambar berupa logo instansi pengembang dan animasi loading sebelum masuk ke halaman utama.






\section{Gambar 1. Tampilan Pembuka}

\section{Halaman Utama}

Tampilan ini merupakan tampilan halaman utama, terdiri dari judul dan menu bagian atas yang dapat diakses serta tombol close untuk menutup media serta dibagian bawah terdapat nama pengembang dan tahun pembuatan

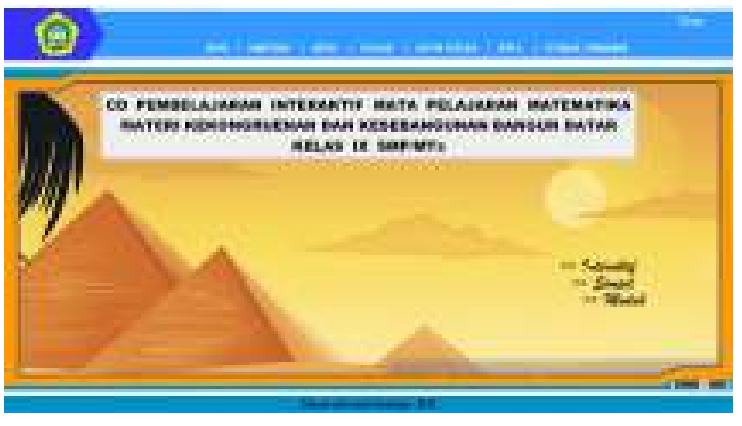

Gambar 2. Tampilan Utama

\section{Halaman Materi}

Halaman ini berisi materi yang akan dipelajari terdiri dari tiga bagian materi yang dapat diklik untuk mengetahui isi dari masing-masing materi.

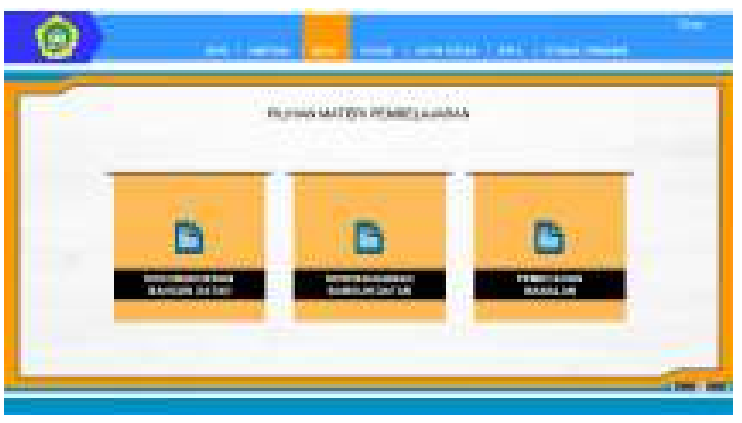

Gambar 3. Tampilan Halaman Materi

\section{Halaman Kompetensi}

Halaman ini berisikan standar kompetensi dan kompetensi dasar yang dimuat didasarkan oleh silabus mata pelajaran matematika yang belaku di MTs. Nahdlatuth Thalabah tahun ajaran 2018/2019. 




Gambar 4. Tampilan Halaman Kompetensi

\section{Halaman Pembelajaran}

Tampilan pembelajaran ini merupakan salah satu contoh isi materi yang terdapat pada CD interaktif pembelajaran matematika materi kekongruenan dan kesebangunan bangun datar.

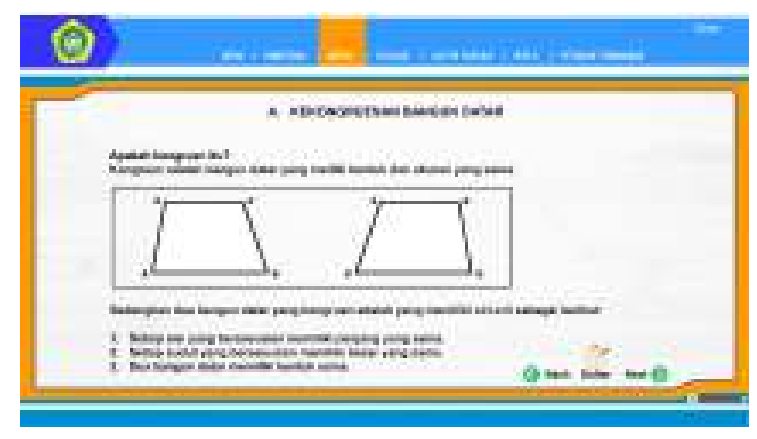

Gambar 5. Tampilan Halaman Pembelajaran

Pada tahap implementasi peneliti melakukan pembelajaran sebanyak empat kali pada kelas yang telah ditentukan. Pada pembelajaran pertama sampai ketiga peneliti melakukan kegiatan pembelajaran menggunakan CD Interaktif dan pada pertemuan terakhir peneliti memberikan soal untuk untuk memperoleh hasil belajar peserta didik dan juga peneliti memberikan angket respon peserta didik dan pendidik untuk mengetahui respon setelah menggunakan CD Interaktif ini.

Semua data yang diperoleh akan dianalisis oleh peneliti. Analisis dilakukan sesuai dengan kualias produk yang dikembangkan yaitu uji kevalidan, uji kepraktisan dan keefektifan Dari data tersebut hasil analisis dapat dilihat pada tabel berikut: 
1. Kevalidan

Tabel 7. Hasil Analisis Kevalidan

\begin{tabular}{cccc}
\hline No & Penilaian & $\begin{array}{c}\text { Rata-Rata } \\
\text { Akhir (Va) }\end{array}$ & Kategori \\
\hline 1 & Ahli Media & 4,6 & Valid \\
\hline 2 & Ahli Materi & 4,1 & Valid \\
\hline 3 & RPP & 4,1 & Valid \\
\hline
\end{tabular}

Sumber : hasil analisis peneliti, 2018

Berdasarkan hasil analisis kevalidan diatas dapat diketahui bahwa pada ahli media mendapat skor akhir (Va) sebesar 4,6, ahi materi memperoleh skor akhir (Va) 4,1 dan RPP dengan skor akhir (Va) 4,1. Setelah mencocokkan rata-rata akhir dengan kategori kevalidan maka CD Interaktif termasuk dalam kategori valid.

2. Kepraktisan.

Tabel 7. Hasil Analisis Kepraktisan

\begin{tabular}{ccc}
\hline Penilaian & Skor & $\begin{array}{c}\text { Klasifika } \\
\text { si }\end{array}$ \\
\hline $\begin{array}{c}\text { Keterlaksanaan } \\
\text { Pembelajaran }\end{array}$ & $80 \%$ & Baik \\
\hline
\end{tabular}

Sumber : hasil analisis peneliti, 2018

Berdasarkan hasil analisis kepraktisan diatas keterlaksanaan pembelajaran memperoleh skor akhir80\% dengan kategori baik. Oleh karena itu, produk yang dihasilkan dapat dikatakan praktis.

3. Analisis Keefektifan.

Tabel 8. Hasil Analisis Keefektifan

\begin{tabular}{lcc}
\hline \multicolumn{1}{c}{ Penilian } & Skor & Klasifikasi \\
\hline Aktivitas Peserta Didik & $80 \%$ & Baik \\
\hline Respon Pendidik & 4 & Baik \\
\hline Respon Peserta Didik & 4 & Baik \\
\hline Tes Hasil Belajar & $84 \%$ & Baik \\
\hline
\end{tabular}


Berdasarkan hasil analisis keefektifan diatas dapat diketahui bahwa pada aktivitas siswa diperoleh skor rata- rata sebesar $80 \%$, angket respon pendidik sebesar 4 , angket respon peserta didik sebesar 4 dan tes hasil belajar siswa sebesar $84 \%$. Dari hasil tersebut setelah mencocokkan tabel keefektifan maka termasuk dalam kategori baik. Dapat disimpulkan CD Interaktiftermasuk kategori efektif.

\section{SIMPULAN DAN SARAN}

\section{Simpulan}

Penelitian R\&D dengan model pengembangan Hanafin dan Peck menghasilkan sebuah CD Interaktif pembelajaran matematika materi kekongruenan dan kesebangunan bangun datar untuk kelas IX SMP/MTs. Produk yang dikembangkan harus diukur untuk menilai kualitas pengembangan, antara lain: (1) Validitas, (2) Kepraktisan dan (3) Keefektifan.

Aspek kevalidan dilihat dari penilaian ahli media yang mendapatkan skor akhir 4,6, ahli media 4,1 dan RPP 4,1 kesemuanya dalam kategori valid. Dapat disimpulkan CD Interaktif yang dikembangkan sudah layak untuk digunakan.

Aspek kepraktisan dilihat dari penlilaian Keterlaksanaan pembelajaran dikelas yang mendapatkan skor akhir $80 \%$ dengan kriteria Baik. Dengan demikian media yang digunakan dapat dipergunakan secara maksimal di kelas.

Aspek keefektifan dilihat dari beberapa instrumen penelitian yaitu aktivitas siswa diperoleh skor akhir sebesar80\%, angket respon pendidik sebesar 4, angket respon peserta didik sebesar 4 dan tes hasil belajar siswa sebesar $84 \%$ dari hasil tersebut setelah mencocokkan dengan tabel keefektifan maka termasuk dalam kategori baik. Dengan demikian, CD Interaktif sudah termasuk kategori efektif.

\section{Saran}

Meskipun CD Interaktif yang telah dikembangkan telah memenuhi kriteria kevalidan, kepraktisan dan keefektifan, masih terdapat beberapa kekurangan yaitu uji coba terbatas satu kelas, sehingga perlu diuji cobakan kepada subjek lain yang lebih besar, materi yang tersedia hanya pada mata pelajaran matematika materi kekongruenan dan kesebangunan bangun datar. Pesatnya perkembangan teknologi juga mempengaruhi pola penggunaan media yang lebih simple dan memungkinkan penggunaan $\mathrm{CD}$ Interaktif berbasis mobile. 


\section{PUSTAKA ACUAN}

Undang undang RI No.20 tahun 2003 tentang sistem pendidikan nasional. 2003. Jakarta: Depdiknas.

Mukhlisah.2015.Pengembangan Kognitif Jean Piaget Dan Peningkatan Belajar Anak Diskalkulia.Jurnal Kependidikan Islam, Volume 6, Nomor 2

Surjono, Herman Dwi. 1995. Pengembangan Computer Asissted Instruction (CAI) untuk Pelajaran Elektronika. Jurnal Kependidikan, (online) No. 2 (XXV): 95-106.(http://herman.elearningjogja.org/PengembanganProgramCAI.pdf, diakses pukul 01:37, 24-11-18).

Sudjana, N dan Ahmad Rivai. 2013. Media Pengajaran. (cetakan ke 11). Bandung: Sinar baru Algensindo

Susilana, Rudi. Riyana, Cepi. 2009. Media Pembelajaran: Hakikat, Pengembangan, Pemanfaatan, dan Penilaian. Bandung: CV Wacana Prima.

Depdiknas.2007. Kajian Kebijakan Kurikulum Mata Pelajaran Matematika. Jakarta: Pusat Kurikulum Balitbang Depdiknas.

Hobri. 2010. Metode Penelitian Pengembangan. Jember : Pena Salsabila.

Riduwan. 2015. Skala Pengukuran Variabel-Variabel Penelitian. Bandung : ALFABETA.

Nasiroh, D. 2014. Pengembangan Model Dengan Pendekatan Kontekstual Pada Materi Barisan Dan Deret Untuk Siswa SMP Terbuka Kelas IX. Skripsi. Yogyakarta: FMIPA. 